INTIQAD: JURNAL AGAMA DAN PENDIDIKAN ISLAM

ISSN 1979-9950 (print) || ISSN 2598-0033 (online), http://jurnal.umsu.ac.id/index.php/intiqad DOI: intiqad.v\%vi\%i.6244

Vol. 13, No. 1 (June 2021)

\title{
Manajemen Pembiayaan Pendidikan dalam Meningkatkan Mutu Pendidikan di Madrasah Aliyah Imam Muslim Serdang Bedagai
}

\author{
Mesiono $^{1^{*}}$, Suswanto ${ }^{2}$, Rahmat Rifai Lubis ${ }^{3}$, Haidir $^{4}$ \\ UIN Sumatera Utara*1 \\ STIT Al Hikmah Tebing Tinggi ${ }^{2}$ \\ STAI Sumatera Medan ${ }^{3}$ \\ UMN Al-Washliyah Medan ${ }^{4}$ \\ *1email: mesiono@uinsu.ac.id \\ 2email:suswanto@stitalhikmah-tt.ac.id \\ 3 email: rahmatrifai@staisumatera-medan.ac.id \\ ${ }^{42}$ email: haidir@umnaw.ac.id
}

\begin{abstract}
This study aims to determine the management of education financing in relation to efforts to improve the quality of education. This research is focused on the managerial head of the Aliyah Imam Muslim madrasah, Serdang Bedagai Regency. This research uses qualitative methods based on descriptive studies. Data collection techniques using observation, interviews, and documentation studies. Data analysis was performed using the Miles and Huberman model stages, namely data reduction, data presentation, and conclusion drawing. The data validity test used triangulation and member crosscheck. The results showed that the management of education financing at Madrasah Aliyah Imam Muslim Serdang Bedagai Regency has a family principle, is effective, efficient, productive, transparent and can be accounted for in accordance with existing procedures, namely the upward hierarchical pattern to the Chairman of the Foundation. In improving the quality of education, the principal is in charge of managing education as best as possible and reporting the draft budget for school financing is given to the Head of the Foundation, the head of madrasah also has the task of how to improve the quality of education in Madrasahs by coordinating every activity with peers in order to realize the quality of education through education financing management
\end{abstract}

\section{Keywords \\ : Education Financing Management, Education Quality.}

\section{Artikel Info \\ Received: \\ 20 January 2021 \\ Revised: \\ 03 April 2021 \\ Accepted: \\ 03 June 2021}

Published:

10 June 2021 


\section{Abstrak}

Penelitian ini bertujuan untuk mengetahui manajemen pembiayaan pendidikan kaitannya dalam upaya peningkatan mutu pendidikan. Penelitian ini difokuskan pada manajerial kepala madrasah Aliyah Imam Muslim Kabupaten Serdang Bedagai. Penelitian ini meggunakan metode kualitatif berbasis studi deskriptif. Teknik pengumpulan data menggunakan observasi, wawancara, dan studi dokumentasi. Analisis data dilakukan dengan tahapan model Miles dan Huberman yakni reduksi data, penyajian data, dan penarikan kesimpulan. Uji keabsahan data menggunakan trianggulasi dan member crosscheck. Hasil penelitian menunjukkan bahwa manajemen pembiayaan pendidikan di Madrasah Aliyah Imam Muslim Kabupaten Serdang Bedagai memiliki asas kekeluargaan, efektif, efisien, produktif, transparan dan dapat dipertanggungjawabkan sesuai dengan prosedur yang ada yakni dengan pola hirarki kea atas kepada Ketua Yayasan. Dalam meningkatkan mutu pendidikan kepala madrasah bertugas mengelola pendidikan sebaik mungkin dan pelaporan rancangan anggaran pembiayaan sekolah diberikan kepada Ketua Yayasan, kepala madrasah juga memiliki tugas bagaimana meningkatkan mutu pendidikan di Madrasah dengan mengkoordinasi setiap kegiatan kepada teman sejawat demi terwujudnya mutu pendidikan melalui manajemen pembiayaan pendidikan.

Kata Kunci : Manajemen Pembiayaan Pendidikan, Mutu Pendidikan

\section{A. Pendahuluan}

Pendidikan merupakan usaha

bersama untuk menjalankan roda pembelajaran yang bertujuan mencerdaskan kehidupan bangsa sebagai amanat UUD Tahun 1945 pada alinea keempat. Pendidikan merupakan sistem yang berproses memberikan pengalaman baru dan pengetahuan lain kepada peserta didik sebagai pemegang estapet pembangunan bangsa. (Huda, 2015). Pemberian pengalaman baru tersebut harus bermakna dan berwarna sistem yang komprehensif. Berjalan atau tidaknya roda pendidikan tergantung pembiayaan dalam pendidikan itu sendiri. (Murtadlo, 2016). Masalah pembiayaan pendidikan merupakan 
masalah utama dalam menjalankan roda pendidikan. Manajemen yang baik dalam pembiayaan pendidikan mempengaruhi mutu pendidikan itu sendiri. (Suryana, 2020). Ini yang menjadi isu utama dalam dunia pendidikan. Isu utama ekonomi pendidikan menurut Elchanan Cohn adalah bagaimana mengidentifikasi dan melakukan pengukuran terhadap nilai ekonomi untuk pendidikan, alokasi sumber-sumber dalam pendidikan, gaji tenaga pendidik, biaya pendidikan dan perencanaan pendidikan. (Cohn, 1979)

Ada beberapa hal yang perlu menjadi perhatian utama dalam membangun dan mengembangkan pendidikan menurut Jhons dan Morphet bahwa hal yang perlu diperhatikan adalah tujuan pendidikan yang akan dicapai, prioritas program pembangunan pendidikan yang menekankan pada aspek kualitas dan kuantitas, upaya meningkatkan pemerataan kesempatan pendidikan, biaya yang dibutuhkan dan alokasi sumber daya dan dana yang akan digunakan untuk penyelenggaraan pendidikan. (Johns \& Morphet, 1975).Tujuan yang akan dicapai dalam manajemen pendidikan adalah pelayanan belajar dan lulusan sebagai output pendidikan itu sendiri. (Chumaidi,
2012). Dalam penyelenggaraan kualitas pendidikan dibutuhkan pembiayaan dengan perhitungan yang akurat sehingga berkesesuaian dengan kualitas yang disyaratkan. Pembiayaan pendidikan merupakan cost yang harus dikeluarkan yaitu perhitungan atau biaya yang dikeluarkan untuk membiayai seluruh kegiatan sekolah yang ada relevansinya dengan pendidikan. Permasalahan ini membutuhkan suatu manajemen yang baik dan transparan.(Abidin, 2017).

Syaiful Sagala menjelaskan bahwa biaya pendidikan mencakup biaya langsung (oleh sekolah, peserta didik dan/atau keluarga peserta didik) dan biaya tidak langsung (seperti inkaminkam yang dilewatkan). (Sagala, 2007). Perhatian terbanyak dicurahkan kepada biaya-biaya langsung. Pada umumnya biaya tidak langsung ditanggung oleh pemerintah dan masyarakat yang berkaitan dengan sistem-sistem sekolah. Perlu diadakan manajemen pembiayaan pendidikan yang baik dalam mengelola biaya pendidikan langsung dan tidak langsung. Kedua jenis pembiayaan pendidikan ini dapat digunakan untuk meningkatkan mutu pendidik dan mutu pendidikan itu sendiri. Pendepat lain 
mengatakan bahwa biaya (cost) merupakan salah satu komponen masukan yang sangat penting dalam penyelenggaraan pendidikan. (Idris, 2010). Pendapat lain lagi mengartikan biaya sebagai semua jenis pengeluaran yang berkenaan dengan penyelenggaraan pendidikan. (Harsono, 2007)

Ada beberapa aspek yang perlu diperhatikan dalam manajemen pembiayaan pendidikan, di antaranya: (1) Memprediksi kebutuhan pendidikan, (2) Alokasi setiap komponen biaya, (3) Analisis sumber, (4) Pengawasan keuangan. Keempat aspek tersebut, harus mendapat perhatian khusus untuk menunjang peningkatan mutu pendidikan. Apabila kebijakan-kebijakan pembiayaan pendidikan direalisasikan dengan sebaik-baiknya, maka proses pendidikan berjalan sesuai dengan apa yang diharapkan.(Komariah, 2018)

Berdasarkan pemaparan penulis tertarik untuk meneliti yang berkaitan dengan manajemen pembiayaan pendidikan di lembaga pendidikan dalam hal ini di Madrasah Aliyah Imam Muslim Kabupaten Serdang Bedagai. Fokus penelitian ini pada dua hal yakni manajemen pembiayaan pendidikan yang dilakukan oleh Kepala Madrasah dan upaya yang dilakukan dalam meningkatkan mutu pendidikan.

\section{B. Metode Penelitian}

.Metode penelitian yang digunakan adalah metode penelitian kualitatif berbasis studi deskriptif deskriftif. Penelitian deskriftif merupakan suatu metode dalam melakukan penelitian status kelompok manusia, suatu objek, satu kondisi Dengan satu system pemikiran atau satu kelas peristiwa pada masa sekarang. Tujuannya adalah untuk membuat gambaran atau lukisan secara sistematis, actual dan akurat tentang fakta-fakta, sifat serta hubungan antara fenomena yang diselidiki.

Teknik pengumpulan data menggunakan observasi, wawancara, dan studi dokumentasi. Analisis data dilakukan dengan tahapan model Miles dan Huberman yakni reduksi data, penyajian data, dan penarikan kesimpulan. Uji keabsahan data menggunakan trianggulasi dan member crosscheck.

\section{Hasil Penelitian}

Sumber dana (keuangan)

Madrasah Aliyah Imam Muslim Kabupaten Serdang Berdagai bersumber 
dari: Pemerintah, melalui dana BOS dan BSM, Yayasan, Masyarakat melalui SPP, Donatur dana luar negeri melalui dana hibah bersumber dari Makkah dan Madinah.

Seluruh sumber dana di atas, bekerjasama dengan jasa perbankan untuk menyimpan keseluruhan dana tersebut. Namun, dalam pengelolaan keuangan Madrasah Aliyah Imam Muslim Kabupaten Serdang Bedagai belum menggunakan sistem digital.

\section{Ekonomi Pendidikan}

Ekonomi pendidikan merupakan suatu pembelajaran bagaimana mengelola sumber dana yang ada dalam dunia pendidikan sehingga dapat berhasilguna dan berdayaguna dalam meningkatkan mutu pendidikan. Masih sedikit sekali, dari lembaga pendidikan, dalam mengelola ekonomi pendidikan yang menitikberatkan dalam pemanfaatan dana untuk meningkatkan mutu pendidik dan pendidikan. Tidak jarang, ada lembaga pendidikan dalam membuat laporan pertranggungjawaban dengan menggunakan laporan fiktif dan tidak sedikit yang transfaran dan jujur. Sebaiknya sumber dana pendidikan yang ada dikelola Dengan menitikberatkan pada pelatihan, pengembangan pengetahuan pendidik dan peserta didik, keterampilan, pikiran, karakter dan seterusnya sehingga mampu mencapai tujuan pendidikan secara efektif dan efisien.

Untuk sekolah formal, ekonomi pendidikan dilaksanakan melalui proses bagaimana hasil pendidikan yang diselenggarakan sekolah dapat bernilai baik (kompeten), pendistribusian pendidikan lanjut diantara individu pendidikan dapat terealisasikan dan bagaimana mewujudkan kegiatan pendidikan seperti apa yang akan diterima peserta didik. Fenomena ini sangat baik untuk diterapkan menuju peningkatan mutu pendidikan. Mutu pendidikan akan berbanding lurus dengan mutu pendidiknya.

Kegiatan belajar mengajar dapat berjalan dengan baik apabila ada sinergi antara penerapan disiplin sekolah, kinerja guru, sarana dan prasarana yang memadai, fasilitas pembelajaran yang baik dan layak dan partisipasi masyarakat (stakeholder). Titik permasalahannya adalah apakah tuntutan pendidikan dipengaruhi oleh sosial atau ekonomi. Pendidikan dapat dipengaruhi oleh seluruh aspek yang ada. Intinya, 


\section{INTIQAD: JURNAL AGAMA DAN PENDIDIKAN ISLAM}

ISSN 1979-9950 (print) || ISSN 2598-0033 (online), http://jurnal.umsu.ac.id/index.php/intiqad DOI: intiqad.v\%vi\%i.6244

Vol. 13, No. 1 (June 2021)

ekonomi pendidikan memiliki kepentingan dalam :

1. Proses pendidikan yang kompeten

2. Distribusi peningkatan kualifikasi akademik pendidik dari S1 menuju S2 dan S3

3. Menitikberatkan berapa yang harus dibelanjakan untuk gaji pendidik (honorium)
4. Menitikberatkan berapa yang harus dikeluarkan untuk kegiatan pendidikan

5. Kegiatan pendidikan mana yang harus diutamakan

Berikut dapat diberikan perkembangan ekonomi pendidikan di Madrasah Aliyah Imam Muslim Kabupaten Serdang Bedagai sebagai berikut:

Tabel I

Realisasi Penerimaan Dana pendidikan MA Imam Muslim 3 Tahun Terakhir

\begin{tabular}{|l|l|c|c|c|}
\hline \multirow{3}{*}{ Sumber Dana } & \multirow{3}{*}{ Jenis Dana } & \multicolumn{3}{|c|}{ Jumlah Dana (Dalam Juta Rupah) } \\
\cline { 3 - 5 } & & $\mathbf{2 0 1 8 / 2 0 1 9}$ & $\mathbf{2 0 1 9 / 2 0 2 0}$ & $\mathbf{2 0 2 0} / 2021$ \\
\cline { 3 - 5 } & & $\mathrm{Rp} 422.400 .000,-$ & $\mathrm{Rp} 621.000 .000,-$ & $\mathrm{Rp} 816.000 .000,-$ \\
\hline Masyarakat & SPP &
\end{tabular}

Sumber: Data Kuangan MA Imam Muslim Tahun 2020

Berdasarkan sumber pendapatan di atas, dapat diberikan kesimpulan bahwa sumber dana yang diperoleh Madrasah Aliyah Imam Muslim Kabupaten Serdang Bedagai dari tiga tahun terakhir mengalami peningkatan yang signifikan.

\section{Kebutuhan Operasional Madrasah}

Sistem penganggaran dana pendidikan selalu direncanakan sebagaimana mestinya menggunakan asas transfaransi dan mengutamakan kepentingan pendidikan. Untuk mendapatkan gambaran penggunaan dana pendidikan, tentunya Madrasah Aliyah Imam Muslim menggunakan aspek perencanaan pengelolaan dana yang ada. Pengalokasian dana pendidikan melibatkan teknik analisis kebutuhan operasional. Sagala (2007) menjelaskan bahwa analisis pembiayaan pendidikan antara lain dilihat dari aspek:

1. Identifikasi kebutuhan yang berhubungan dengan pembiayaan besarnya kebutuhan

2. Entroliment tentang kebutuhan setiap peserta didik

3. Jenis kebutuhan tiap peserta didik

4. Kebutuhan sarana dan prasarana

5. Biaya program

Alokasi kebutuhan penyelenggaraan pendidikan harus 


\section{INTIQAD: JURNAL AGAMA DAN PENDIDIKAN ISLAM}

ISSN 1979-9950 (print) || ISSN 2598-0033 (online), http://jurnal.umsu.ac.id/index.php/intiqad

DOI: intiqad.v\%vi\%i.6244

Vol. 13, No. 1 (June 2021)

mengacu pada asas kebutuhan yang urgen, sehingga dapat mengukur seberapa besar dana yang harus dikeluarkan. Biasanya penggunaan dana pendidikan berkisar operasional sekolah yang meliputi gaji guru, operasional pengajaran, ATK, perawatan dan pemeliharaan gedung, penggantian meja dan kursi yang rusak serta kebersihan dan kesehatan. Kesemua dana ini harus dimanajemen sebaik mungkin sehingga tidak ada kebocoran penggunaan dana yang tidak semestinya. Dalam mengeluarkan dana operasional sekolah harus memakai asas mana yang harus didahulukan dan mana yang harus dibelakangkan.

\section{Kebutuhan Peserta Didik}

Meningkatkan kualitas belajar peserta didik adalah dengan memperhatikan dan mengutakan kebutuhan peserta didik. Kebutuhan peserta didik yang mampu meningkatkan kualitas pembelajarannya adalah ketersediaan buku di perpustakaan yang relevan dengan seluruh mata pelajaran, untuk Pondok Pesantren Imam Muslim perpustakaannya rata-rata memiliki perbendaharaan buku berbahasa Arab.

Tersedianya laboratorium, terutama laboratorium Bahasa sangat menunjang kemajuan bahasa peserta didik dan praktik pembelajaran di Madrasah Aliyah Imam Muslim. Alat olahraga yang lengkap juga membantu psikomotor peserta didik dalam pembelajaran dan menghilangkan rasa jenuh peserta didik. Lapangan olahraga yang baik dan halaman yang luas juga dimiliki Madrasah Aliyah Imam Muslim. Untuk itu, Kepala Sekolah harus mampu menghitung setiap item kebutuhan peserta didik dan harus mampu mengalokasikannya dalam setiap menyusun anggaran (perencanaan).

Tabel II

Realisasi Kebutuhan Peserta Didik MA Imam Muslim Kabupaten Serdang Bedagai

\begin{tabular}{|l|l|l|l|}
\hline No & \multicolumn{1}{|c|}{ Jenis Kebutuhan Peserta Didik } & \multicolumn{1}{|c|}{ Jumlah } & \multicolumn{1}{|c|}{ Keterangan } \\
\hline 1 & Laboratorium Komputer & 1 & Permanen \\
\hline 2 & Buku Perpustakaan & 4.567 & Baik \\
\hline 3 & Peralatan Olahraga & 2 Unit & Baik \\
\hline 4 & Lapangan Olahraga & 1 & Baik \\
\hline 5 & Masjid (Menggunakan AC) & 1 (AC 7 Unit) & Baik \\
\hline 6 & Meja Belajar & 145 & Baik \\
\hline
\end{tabular}


INTIQAD: JURNAL AGAMA DAN PENDIDIKAN ISLAM

ISSN 1979-9950 (print) || ISSN 2598-0033 (online), http://jurnal.umsu.ac.id/index.php/intiqad

DOI: intiqad.v\%vi\%i.6244

Vol. 13, No. 1 (June 2021)

\begin{tabular}{|l|l|l|l|}
\hline 7 & Kursi Belajar & 290 & Baik
\end{tabular}

Sumber: Data Keungan MA Imam Muslim Tahun 2020

\section{Perlengkapan dan Peralatan}

Perlengkapan dan peralatan pendidikan, baik bergerak dan tidak bergerak, dibutuhkan untuk menunjang proses pembelajaran baik langsung maupun tidak langsung. Perlengkapan dan peralatan sekolah disediakan untuk tiga hal, yaitu (1) keperluan kantor untuk kepala dan tata usaha, (2) keperluan pendidik, dan (3) ruang belajar peserta didik. Kepala Madrasah harus mampu memprediksi dan memandang kebutuhan tambahan terhadap perlengkapan dan peralatan pendidikan, diantaranya media pembelajaran, gedung ibadah dan gudang. Terkhusus untuk pondok pesantren gajebo (tempat tamu atau orangtua berkunjung melihat anaknya). Investasi perlengkapan dan peralatan harus diarahkan kepada tiga komponen dimaksud. Kegiatan ini meliputi perencanaan kebutuhan, pengadaan, penyimpanan, inventarisasi, pemeliharaan dan penghapusan. Di samping itu, harus diadakan media digital dalam pembelajaran untuk meningkatkan animo peserta didik dalam belajar.

TABEL III

Realisasi perlengkapAn dan Peralatan MA Imam Muslim Kabupaten Serdang Bedagai

\begin{tabular}{|l|l|l|l|}
\hline No & Jenis Perlengkapan dan Peralatan & Jumlah & Keterangan \\
\hline 1 & Ruang Belajar (Bertingkat) & 9 & Permanen \\
\hline 2 & Kantor Kepala Madrasah & 1 & Permanen \\
\hline 3 & Kantor Guru & 1 & Permanen \\
\hline 4 & Kantor Tata Usaha & 1 & Permanen \\
\hline 5 & Komputer Tata Usaha & 2 & Baik \\
\hline 6 & Komputer & 14 Unit & Baik \\
\hline 7 & Infocus & 9 & Baik \\
\hline 8 & Pos Satpam & 1 & Permanen \\
\hline
\end{tabular}

Sumber : Inventaris Madrasah Aliyah Imam Muslim Tahun 2020

\section{Pemeliharaan dan Perawatan}

Madrasah Aliyah Imam Muslim Kabupaten Serdang Bedagai hamper setiap tahun meningkatkan pembangunan perlengkapan dan peralatan pendidikan meliputi sarana dan prasarana gedung, termasuk di dalamnya gudang. Banyak sekolah (madrasah) yang tidak begitu memperdulikan inventaris peralatan dan perlengkapan 
INTIQAD: JURNAL AGAMA DAN PENDIDIKAN ISLAM

ISSN 1979-9950 (print) || ISSN 2598-0033 (online), http://jurnal.umsu.ac.id/index.php/intiqad DOI: intiqad.v\%vi\%i.6244

Vol. 13, No. 1 (June 2021)

sehingga terkesan apa adanya. pengadaan atau perbaikan barang yang Pencatatan perlengkapan dan peralatan dicatat telah rusak dalam RAPBSnya. pendidikan sangat dibutuhkan untuk merencanakan, merealisasikan dan melengkapi peralatan dan perlengkapan apa yang harus diutamakan. Pencatatan peralatan dan perlengkapan yang rusak (cacat) sangat dibutuhkan untuk melakukan perawatan dan pemeliharaan sehingga dapat menekan angka cost sekolah. Kegiatan pengurusan, penyelenggaraan, pengaturan dan pencatatan barang perlengkapan milik madrasah dapat mempengaruhi baik atau tidaknya penyelenggaraan pendidikan itu sendiri. Hal seperti ini jangan dipandang sebelah mata (dianggap enteng). Dokumen pencatatan perlengkapan dan peralatan yang baik atau rusak dapat memberikan masukan kepada Kepala Madrasah dalam merencanakan Hal ini juga mampu menghindari tumpang tindih pembelanjaan peralatan dan perlengkapan jadi terkesan boros. Untuk itulah, seharusnya madrasah (sekolah) harus menempatkan seseorang sebagai petugas untuk mencatat barang masuk, barang diterima, barang yang telah dicatat, barang yang sedang digunakan, pengaturan barang masuk dan keluar, jadual perawatan berkala dan lain sebagainya. Kesemuanya harus dicatat dan diinventariskan secarfa rapih, baik dan benar. Pencatatan ini bertujuan untuk mengambil keputusan apabila terjadi isidental (keadaan darurat) dalam pengadaan perlengkapan dan peralatan pendidikan. Ini guna pencatatan untuk melakukan pemeliharaan dan perawatan perlengkapan dan peralatan pendidikan.

Tabel IV

Realisasi Dana Perawatan Dan Pemeliharaan MA Imam Muslim Kabupaten Serdang Bedagai

\begin{tabular}{|l|l|l|l|}
\hline Nomor & \multicolumn{1}{|c|}{ Jenis Pemeliharaan dan Perawatan } & $\begin{array}{c}\text { Jumlah Dana } \\
\text { (Dalam Juta } \\
\text { Rupiah) }\end{array}$ & Keterangan \\
\hline 1 & Pengecatan Gedung Asrama & Rp $14.500 .000,-$ & Tuntas \\
\hline 2 & Penambahan Meja dan Kursi & Rp $19.500 .000,-$ & Tuntas \\
\hline 3 & Perbaikan Pintu Kamar Mandi Putra & Rp $3.500 .000,-$ & Tuntas \\
\hline 4 & Pembuatan Menara Masjid & Rp $45.000 .000,-$ & Tuntas \\
\hline 5 & Pengadaan Mesin Air Putri & Rp $7.800 .000,-$ & Tuntas \\
\hline
\end{tabular}


ISSN 1979-9950 (print) || ISSN 2598-0033 (online), http://jurnal.umsu.ac.id/index.php/intiqad DOI: intiqad.v\%vi\%i.6244

Vol. 13, No. 1 (June 2021)

Sumber: Dana Realisasi Pemeliharaan dan Perawatan Madrasah Aliyah Imam Muslim Tahun 2020

\section{Sarana dan Prasarana}

Ketersediaan biaya dan kemampuan kepala madarasah dalam pengadaan sarana dan prasarana pendidikan dapat mempengaruhi kinerja guru dan keberhasilan pendidik serta peserta didik dalam proses belajar dan mengajar. Pengadaan ini dipengaruhi dana yang ada dan manajerial kepala madrasah dalam merencanakan dan mengadakan sarana dan prasarana mempengaruhi maju atau tidaknya lembaga pendidikan yang dipimpinnya.

Kejelian dan ketelitian kepala madrasah dalam menganalisis kebutuhan dengan keterbatasan potensi sekolahnya akan tetap menjaga mutu pendidikan membutuhkan dicision making yang tepat guna. Indriyanto (1998) menyatakan terdapat dua fenomena yang dapat diamati berkenaan Dengan ketersediaan sarana dan prasarana sekolah, yaitu :

1. Fenomena keterbatasan yaitu keterbatasan sarana dan prasarana merupakan salah satu faktor yang menonjol dalam pelaksanaan kebijakan dan program sekolah yang berada diperkotaan apalagi yang berada dipedesaan.

2. Pemanfaatan, yaitu dilain pihak, unit-unit kerja dan sekolah yang telah memiliki sarana dan prasarana yang memadai ternyata kurang memanfaatkannya. Hal ini terjadi karena ketersediaan sarana dan prasarana tidak dilihat dari fungsinya, tetapi sebagai simbol status.

Berdasarkan konteks di atas, bahwa kepala madrasah (sekolah) harus memiliki persyaratan pengadaan sarana dan prasarana Dengan mengadakan daftar prioritas keperluan sarana dan prasarana yang dilakukan oleh tenaga kependidikan yang professional.

\section{Gaji Guru}

Hal yang paling menarik dalam pembiayaan pendidikan adalah gaji guru. Unik, tetapi tidak jarang sekolah mengalami kesulitan dalam pengadaan gaji guru ketika pemasukan dana pendidikan tidak sebagaimana mestinya. Pengadaan gaji guru tentunya diambil dari dana SPP yang diberikan peserta 
ISSN 1979-9950 (print) || ISSN 2598-0033 (online), http://jurnal.umsu.ac.id/index.php/intiqad

DOI: intiqad.v\%vi\%i.6244

Vol. 13, No. 1 (June 2021)

didik setiap bulannya. Kepala Madrasah harus mampu melihat sejauhmana proses pembayaran SPP sehingga dapat mengambil keputusan kapan gaji akan diberikan. Jika dana yang masuk tidak sesuai dengan apa yang diharapkan, maka kepala madrasah harus mampu mengambil jalan keluar, sebab tidak mungkin gaji guru tidak diberikan sesuai tanggal yang disepakati bersama. Sistem penggajian guru di Madrasah Aliyah Imam Muslim Kabupaten Serdang Bedagai masih manual, belum menggunakan sistem penggajian digital. Sebaiknya, Kepala Madrasah harus dapat mengagendakan kapan penggajian guru dengan menggunakan digital agar lebih teratur, terarah dan transfaran serta modernisasi gaji. Baik atau tidaknya (rendah) mutu pendidikan dipengaruhi beberapa faktor, menurut $\mathrm{PH}$. Combs (1968) sebagai berikut:

1. Gaji para guru yang rendah yaitu tidak cukup untuk memenuhi nafkah hidup dan menyekolahkan anak-anaknya.

2. Menggunakan guru-guru yang tidak kualified baik dilihat dari latar belakang pendidikan maupun pertumbuhan
3. Rasio antara murid dan guru tidak seimbang yaitu jumlah peserta didik perkelas melebihi aturan yang disyaratkan.

4. Menggunakan double sift sistem yaitu ada kelas pagi dan ada kelas sore dengan menggunakan rung kelas yang sama.

Disetiap lembaga pendidikan, tentunya berbeda dalam proses penggajian dan besar santunan gaji setiap individu guru. Hal ini menjadi fenomena unik disetiap lembaga pendidikan, mengapa harus beda, apa yang menyebabkan berbeda dan bagaimana mengatasi perbedaan yang ada. Pada umumnya lembaga pendidikan menggaji gurunya berdasarkan jumlah jam yang diampuh dan mungkin perbedaan kesetaraan mata pelajaran, seperti di SMK, antara guru biasa dengan guru produktif pasti berbeda besar satuan gajinya. Perbedaan kesetaraan gaji ini, tentunya dapat mempengaruhi kinerja guru, apalagi masih ada sekolah (madrasah) yang memberikan besar satuan gaji perjamnya masih terbilang sangat rendah $(\mathrm{Rp}$ 25.000,-/jam). Di Madrasah Aliyah Imam Muslim Kabupaten Serdang jabatannya. 
ISSN 1979-9950 (print) || ISSN 2598-0033 (online), http://jurnal.umsu.ac.id/index.php/intiqad DOI: intiqad.v\%vi\%i.6244

Vol. 13, No. 1 (June 2021)

Bedagai telah mampu menggaji guru perjam sebesar Rp 35.000,-.

Malechar mengemukakan bahwa hal yang mempengaruhi gaji guru adalah tingkat akademis, jenis kelamin, profesi, aktivitas kerja (mengajar), riset, adminsitrasi dan usia. Di samping itu, bahwa mengajar sekolah publik tetap merupakan suatu panggilan dengan plafon gaji relatif kecil dibanding bidang-bidang lainnya. Sagala (2007) menjelaskan bahwa kondisi ini menunjukkan:
1. Penghargaan terhadap guru mengalami deplasi yang tajam.

2. Kinerja guru tidak dapat diukur.

3. Kualitas pendidikan sulit ditingkatkan.

4. Kualitas Sumber Daya Manusia hasil pendidikan tidak kompetitif.

5. Pertumbuhan ekonomi rendah dan rentan terhadap krisis karena ketidakmampuan Sumber Daya Manusia mengendalikannya.

6. Kerugian lain semacamnya.

TABEL V

Realisasi Penggajian Guru MA Imam Muslim Kab. Serddang Bedagai

\begin{tabular}{|l|l|ll|ll|}
\hline Nomor & Tahun Pelajaran & $\begin{array}{l}\text { Besaran Satuan Gaji Guru } \\
\text { (Dalam Juta Rupiah) }\end{array}$ & \multicolumn{2}{|c|}{ Keterangan } \\
\hline 1 & $2018 / 2029$ & Rp 330.174.000,- & $\begin{array}{l}\text { Diberikan } \\
\text { Manual }\end{array}$ & Secara \\
\hline 2 & $2019 / 2020$ & Rp 360.510.000,- & $\begin{array}{l}\text { Diberikan } \\
\text { Manual }\end{array}$ & Secara \\
\hline 3 & $2020 / 2021$ & Rp 425.694.000,- & $\begin{array}{l}\text { Diberikan } \\
\text { Manual }\end{array}$ & Secara \\
\hline
\end{tabular}

Sumber: Data Keuangan MA Imam Muslim Tahun 2020

Berdasarkan besarnya pemasukan SPP pertahun dari peserta didik Madrasah Aliyah Imam Muslim Kabupaten Serdang Bedagai, dibandingkan dengan pengeluaran gaji guru masih berbanding lurus sehingga banyak kesempatan bagi Kepala Madrasah untuk menaikkan gaji guru perjamnya, tentunya tidak terlepas dari ijin yayasan. Gaji guru seharusnya diberikan sesuai kebutuhan riel untuk memenuhi kebutuhan hidup dan keluarganya. Itu sebabnya, pemerintah menggulirkan sertifikasi untuk mengimbangi antara pemasukan dan pengeluaran guru dalam hidup dan kehidupannya. Jika pembiayaan penggajian guru sudah dapat 
ISSN 1979-9950 (print) || ISSN 2598-0033 (online), http://jurnal.umsu.ac.id/index.php/intiqad

DOI: intiqad.v\%vi\%i.6244

Vol. 13, No. 1 (June 2021)

ditingkatkan, maka kualitas dan kinerja guru dapat terukur, perbaikan sistem pembelajaran dapat segera terwujud dan memberikan sanksi kepada guru yang tidak mematuhi aturan dan memberikan kepada guru penghargaan apabila mematuhi setiap aturan. Dengan demikian, mutu pendidikan dapat terealisasi secara efektif dan efisien.

\section{RAPBS}

Sebagian dana membiayai roda pendidikan diperoleh dari masyarakat (SPP). Dalam usaha mengumpulkan dana dan telah terealisasi, maka ditetapkan dalam Rancangan Anggaran Pendapatan dan Belanja Sekolah (RAPBS). Dalam menyusun RAPBS maka harus diketahui terlebih dahulu budget yang ada. Menurut Sagala (2007) budget (rencana) adalah:

1. Rencana operasional keuangan mencakup estimasi tentang pengeluaran untuk suatu periode/kurun waktu.

2. Rencana sistematik untuk efisiensi pemanfaatan tenaga, industri (sumber).

3. Rencana keuangan yang diprioritaskan dengan pola pengawasan operasional pada masa datang suatu lembaga.

Berhubungan dengan perencanaan anggaran pendapatan belanja sekolah, ada beberapa hal terpenting yang harus diperhatikan sebelum menyusun RAPBS sebagai berikut:

1. Pelayanan peserta didik, baik perlengkapan dan peralatan belajarnya. Ini dijadikan prioritas utama, sebab baiknya suatu lembaga pendidikan tergantung bagaimana pelayanannya kepada peserta didik.

2. Lembaga pendidikan sebaiknya memperhatikan kerjasama dengan lembaga terkait perihal kompetensi, baik pendidik maupun peserta didiknya.

3. Lembaga pendidikan wajib memberikan layanan psikologis (bimbingan dan konseling) untuk membantu peserta didik dalam mengembangkan potensi dirinya.

4. Lembaga pendidikan harus mempersiapkan daya dukung lembaga menuju peningkatan mutu pendidikan (di dalamnya output pendidikan). 
ISSN 1979-9950 (print) || ISSN 2598-0033 (online), http://jurnal.umsu.ac.id/index.php/intiqad

DOI: intiqad.v\%vi\%i.6244

Vol. 13, No. 1 (June 2021)

5. Memperhatikan besaran dan hitungan gaji guru, staf dan pegawai.

6. Menyediakan bahan dan fasilitas penunjang proses pembelajaran.

\section{Pengawasan}

Pengawasan

pembiayaan

pendidikan di Madrasah Aliyah Imam Muslim Kabupaten Serdang Bedagai selalu mendapat pengawasan dari Yayasan, apabila terdapat perbaikan dapat dilakukan secara musyawarah. Estimasi pemasukan keuangan dari sumber-sumber yang ada ternyata jumlahnya kecil, maka Kepala Madrasah harus berusaha mencari sumber dana yang lain, untuk menutupi kenyataan yang ada sehingga pendidikan berjalan sebagaimana mestinya. Pengawasan dibutuhkan untuk melihat sejauhmana kepala madrasah mampu menyusun rancangan pembiayaan pendidikan sesuai kurun waktu yang diharuskan dan untuk melihat apakah ada terjadi penyimpangan perancangan dan aplikasi rancangan. Untuk kelancaran proses RAPBS, maka yayasan harus membentuk tim audit internal untuk melihat apakah RAPBS yang disusun sudah terealisasi sebagaimana susunannya. Monitoring dan evaluasi
(Monev) pemanfaatan anggaran pembiayaan pendidikan harus mendapat perhatian dan perirotas utama untuk menghindari kecurigaan. Monev dituangkan dalam bentuk berita acara, pelaporan dan nota kesepakatan bersama serta surat pertanggungjawaban mutlak yang ditandatangani oleh kepala madrasah. Dengan demikian, pengawasan dan penerapan RAPBS sejalan sehingga pendidikan dapat berjalan secara efektif dan efisien.

Berdasarka apa yang telah dijelaskan di atas bahwa manajemen pembiayaan pendidikan di Madrasah Aliyah Imam Muslim Kabupaten Serdang Bedagai memiliki asas kekeluargaan, efektif, efisien, produktif, transfaran dan dapat dipertanggungjawabkan sesuai prosedur kepada Ketua Yayasan. Kepala Madrasah bertugas mengelola pendidikan sebaik mungkin dan pelaporan RAPBS diberikan kepada Ketua Yayasan, kepala madrasah juga memiliki tugas bagaimana meningkatkan mutu pendidikan di Madrasah Aliyah Imam Muslim Kabupaten Serdang Bedagai dengan mengkoordinasi setiap kegiatan kepada teman sejawat demi terwujudnya mutu pendidikan melalui 
manajemen pembiayaan pendidikan yang disusun oleh Tim RAPBS.

\section{D. simpulan}

Berdasarkan pembahasan di atas, maka dapat diambil beberapa kesimpulan yakni dalam merencanakan pembiayaan pendidikan Kepala Madrasah Aliyah Imam Muslim Kabupaten Serdang Bedagai melaksanakan beberapa dimensi sebagai berikut : (1) perencanaan yang berisikan pengumpulan data, pengolahan data, diagnosa, perumusan kebijakan, estimasi kebutuhan, melakukan penganggaran kebutuhan dana dan memilih sasaran, (2) merumuskan rencana, (3) perincian rencana, (4) implementasi rencana, dan (5) revisi dan melakukan perencanaan setelahnya. Kemudian Pelaksanaan manajemen pembiayaan pendidikan terpenuhi dan mampu direalisasikan di Madrasah Aliyah Imam Muslim Kabupaten Serdang Bedagai. Pada pengawasan penggunaan biaya pendidikan di Madrasah Aliyah Imam Muslim Kabupaten Serdang Bedagai senantiasa dilaksanakan dengan RAPB. Kepala Madrasah Aliyah Imam Muslim Kabupaten Serdang Bedagai telah mampu melakukan manajemen pembiayaan pendidikan secara efektif dan efisien. Upaya yang dilakukan Kepala Madrasah Aliyah Imam Muslim Kabupaten Serdang Bedagai dalam meningkatkan mutu pendidikan adalah dengan memberikan kesempatan kepada seluruh staf pendidik untuk melanjutkan perkuliahan ketingkat yang lebih tinggi, seperti ada pendidik yang kuliah S1 (karena memang belum sarjana), ada pendidik yang kuliah S2 dan bahkan S3.

\section{E. Daftar Pustaka}

Abidin, A. A. (2017). Manajemen pembiayaan pendidikan tinggi dalam upaya peningkatan mutu (Studi kasus pada perguruan tinggi swasta menengah di Surabaya). Jurnal Penjaminan Mutu, 3(1), 8799.

Chumaidi, M. (2012). Mengoptimalkan Peran Manajemen Organisasi Dalam Pengelolaan Pendidikan Tinggi. SAINTEKBU, 5(1), 55-63. https://doi.org/10.32764/saintekbu.v $5 \mathrm{i} 1.56$

Cohn, E. (1979). The Economic of Education. Ballinger Pubilishing Company.

Harsono. (2007). Pengelolaan Pembiayaan Pendidikan. Pustaka Book Publisher.

Huda, M. (2015). Peran Pendidikan Islam Terhadap Perubahan Sosial. Edukasia: Jurnal Penelitian 
INTIQAD: JURNAL AGAMA DAN PENDIDIKAN ISLAM

ISSN 1979-9950 (print) || ISSN 2598-0033 (online), http://jurnal.umsu.ac.id/index.php/intiqad DOI: intiqad.v\%vi\%i.6244

Vol. 13, No. 1 (June 2021)

Pendidikan Islam, 10(1), 165-188. http://dx.doi.org/10.21043/edukasia .$v 10 \mathrm{i} 1.790$

Idris, R. (2010). APBN pendidikan dan mahalnya biaya pendidikan. Lentera Pendidikan: Jurnal Ilmu Tarbiyah Dan Keguruan, 13(1), 92-110.

https://doi.org/10.24252/lp.2010v13 n1a7

Johns, R. L., \& Morphet. (1975). The Economic and Financing of Education, A System Aparoach. Prentice Hall Inc.

Komariah, N. (2018). Konsep Manajemen Keuangan Pendidikan. Al-Afkar: Jurnal Keislaman \& Peradaban, 6(1), 67-94. https://doi.org/10.32520/afkar.v6i1. 192

Murtadlo, M. (2016). Strategi Pembiayaan Pendidikan pada Madrasah Swasta Unggulan. Edukasi: Jurnal Penelitian
Pendidikan Agama Dan

Keagamaan, 14(1), 97-116. http://www.jurnaledukasikemenag. org/index.php/edukasi/article/viewF ile/14/14

Sagala, S. (2007). Manajemen Strategik Dalam Peningkatan Mutu Pendidikan, Pembukaan Ruang Kreativitas, Inovasi dan Pemberdayaan Potensi Sekolah Dalam Sistsem Otonomi Sekolah. Alfabeta.

Suryana, S. (2020). Permasalahan mutu pendidikan dalam perspektif pembangunan pendidikan. Edukasi, 14(1), 1-12. https://doi.org/10.15294/edukasi.v1 4i1.971. 